\title{
The large jaguar that lived in the past of México: a forgotten fossil
}

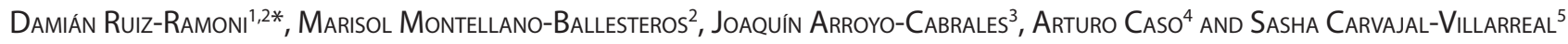 \\ ${ }^{1}$ Centro Regional de Investigaciones Científicas y Transferencia Tecnológica de La Rioja, (CRILAR), S/N, F5301, Provincia de La \\ Rioja, CONICET, Anillaco, La Rioja, Argentina. Email: drramoni@gmail.com (DR-R). \\ 2 Departamento de Paleontología, Instituto de Geología, Universidad Nacional Autónoma de México, Ciudad Universitaria, \\ 04510, Ciudad de México, México. Email: marmont@unam.mx (MM-B). \\ ${ }^{3}$ Laboratorio de Arqueozoología, Subdirección de Laboratorios y Apoyo Académico, Instituto Nacional de Antropología e \\ Historia, Moneda 16, Colonia Centro Histórico, Del. Cuauhtémoc, 06010, Ciudad de México, México. Email: arromatu@hotmail. \\ com (JA-C). \\ ${ }^{4}$ Subsecretaría de Planeación y Política Ambiental, Secretaría de Medio Ambiente y Recursos Naturales, Ejército Nacional 223, \\ Colonia Anáhuac, Delegación Miguel Hidalgo, 11320, Ciudad de México, México. Email: leopardproj@hotmail.com AC). \\ ${ }^{5}$ Predator Conservation A. C. Calzada al Desierto de Los Leones 4448, Ciudad de México, México 01700. Email: zyanya4@hotmail. \\ com (SC-V). \\ *Corresponding author
}

In the 1970's, Oswald Mooser delivered to the Instituto de Geología, Universidad Nacional Autónoma de México, a fossil jaw recovered from the Chapala region, Jalisco, that he identified as Panthera onca. The collection label indicates doubts about this taxonomic assignment; an issue that remains unsolved. The aim of this work is to study the taxonomy and biogeographic implications of this material. With this aim, morphological and morphometric comparisons were made using fossil and current feline specimens. Additionally, a review of the fossil record of $P$. onca in Mexico was carried out using the material deposited in collections and reported in the literature. Our results indicate that the jaw from Jalisco belongs to a large Pleistocene form of jaguar historically called $P$. onca augusta. With the present record, there is a total of 10 paleontological localities in México where fossil jaguar records have been reported. Curiously, only one of these locations matches with the current distribution of this feline in North America, the San Josecito Cave in Nuevo León. With this information, there is evidence to confirm that the range distribution of the jaguar has been reduced significantly since the Pleistocene to the present.

En los 70, Oswald Mooser entregó al Instituto de Geología, Universidad Nacional Autónoma de México, una mandíbula fósil recuperada de la región de Chapala, Jalisco, que identificó como Panthera onca. La ficha de colección señala dudas sobre esta asignación taxonómica, un tema que no se ha resuelto. El objetivo de este trabajo fue estudiar la taxonomía y las implicaciones biogeográficas de este material. Para esto, se realizaron comparaciones morfológicas y morfométricas utilizando especímenes de felinos fósiles y actuales. Adicionalmente, se realizó una revisión del registro fósil de $P$. onca en México utilizando el material depositado en colecciones y reportado en la literatura. Nuestros resultados indican que la mandíbula de Jalisco pertenece a una forma grande de jaguar del Pleistoceno que históricamente ha sido llamado $P$. onca augusta. Con este registro, hay un total de 10 localidades paleontológicas en México donde se han reportado jaguares fósiles. Curiosamente, solo uno de estos lugares coincide con la distribución actual de este felino en América del Norte, la Cueva de San Josecito en Nuevo León. Con esta información, hay evidencia para confirmar que el rango de distribución del jaguar se ha reducido significativamente desde el Pleistoceno hasta el presente.

Key words: distribution; felid; San Josecito Cave; Chapala; Panthera onca augusta.

(C) 2020 Asociación Mexicana de Mastozoología, www.mastozoologiamexicana.org

\section{Introduction}

Jaguar is the common name of the big New-World felid Panthera onca (Linnaeus 1758). This species is the only American extant species of the pantherine lineage (Seymour 1989; Barnett et al. 2016). The jaguar is characterized by its similar appearance with the African leopard, $P$. pardus; both have spots and rosettes on their skin, but the jaguar is slender, and its teeth are smaller (Seymour 1989). phylogenetically, $P$. onca is more related to the leopard $P$. pardus, the lion $P$. leo, the extinct lion cave $P$. spelaea, and the American lion P. atrox, than to the snow leopard P. uncia, the tiger $P$. tigris, the extinct $P$. palaeosinensis, and $P$. blytheae (Johnson et al. 2006; Mazák et al. 2011; Tseng et al. 2014). Nevertheless, the origin of the jaguar is not yet clear. Some authors have indicated that there were forms that lived in
Eurasia and part of Africa during most of the Pleistocene, under two subspecies: $P$. onca gombaszoegensis and $P$. onca georgica (Shultz et al. 1985; Hemmer and Kahle 2005; Hemmer et al. 2001; 2003; 2010); but other authors differed from this taxonomic scenario, and considered the Eurasian jaguar-like animal as a different species, $P$. gombaszoegensis (Arroyo-Cabrales 2002; O'Regan 2002; Marciszak 2014; Stimpson et al. 2015).

The oldest fossil record of $P$. onca in North America comes from the Middle Pleistocene of northern United States (Shultz et al. 1985; Seymour 1989), and the species became abundant during the Late Pleistocene (Kurtén 1973). Some authors argued that it was probably present in the continent since the Late Pliocene or Early Pleistocene times (Johnson et al. 2006). 
The distribution of this species in the past ranged from Washington, United States, to Chilean Tierra del Fuego (Seymour 1989; Soibelzon and Prevosti 2013; Arias-Alzate et al. 2017; Prevosti and Forasiepi 2018). Nowadays, its distribution is restricted from northern México to northern Argentina, but it should be noted that this distribution is constituted mostly patchy (Seymour 1989; de la Torre et al. 2017; Quigley et al. 2017; Arias-Alzate et al. 2017; Jędrzejewski et al. 2018). Curiously, laying México in the northern part of the current species distribution, the fossil record in this country is poorly represented (Arroyo-Cabrales 2002), unlike in United States (Kurtén 1973).

In order to contribute to the knowledge of the evolutionary history of the jaguar in North America and specifically in México, this study focuses on a fossil right jaw of a this feline (Figure 1) from San Luis Soyatlán, a town sitting in the southern border of the Chapala Lake, in the State of Jalisco. This specimen was donated to the Museum of the Instituto de Geología, Universidad Nacional Autónoma de México, by Osvaldo Mooser (swiss dentist and amateur paleontologist) in 1977 (Figure 2), but was never studied thoroughly and officially entered the IGM Paleontological Collection. Despite its fragmentary nature, its study provides relevant evolutionary and taxonomic information. Additionally, to the study of this material, a review of the fossil record of $P$. onca for México is presented with the biogeographic and ecological implications.

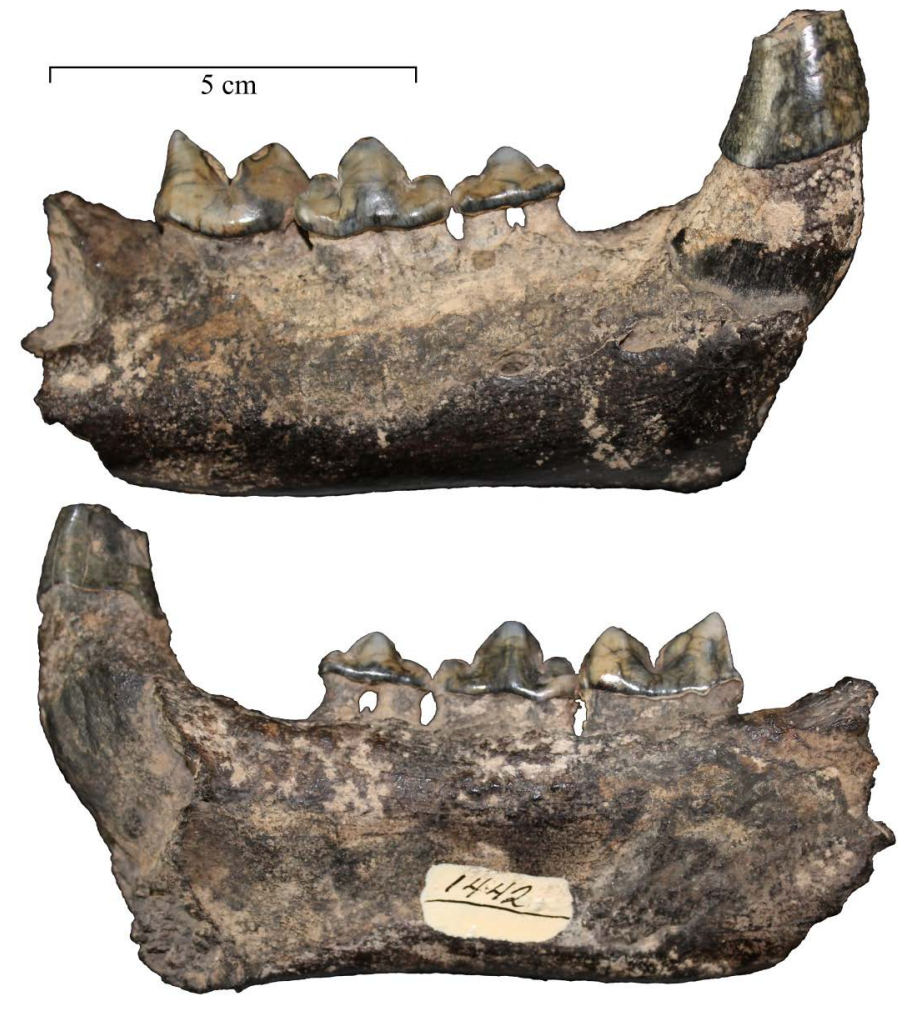

Figure 1. Buccal (left) and lingual (right) views of the specimen of Panthera onca IGM 9518.

\section{Materials and Methods}

The fossil material (IGM 9518) is housed at the Colección Nacional de Paleontología, Museo Ma. Del Carmen Perrilliat (IGM), at the Instituto de Geología, Universidad Nacional Autónoma de México (UNAM) in México City, México.

Comparison. Specimen IGM 9518 was compared with material of Leopardus spp.: from the Museo Estación Biológica de Rancho Grande, Venezuela: EBRG 563, 589, $1183,1374,1493,1617,3017,2214,3159,9609,805$, $1618,1904,3200,17585$; Panthera leo: from the Museo Argentino de Ciencias Naturales Bernardino Rivadavia, Mastozoología, Argentina: MACN-Ma 23.1; Argentinean P. onca: frm the Museo de La Plata, Argentina: MLP 10-9, and from MACN 26.217; Venezuelan P. onca: EBRG 3196 (female), 20224 (female), 20238 (male), 21702 (female), 21703 (male), 22467; Puma concolor: EBRG 128, 275, 1418, 1705, 1902, 2304, 17059, 20787, 22400.

Also, some comparison data were obtained from bibliographic sources, as Carbot-Chanona and Gómez-Pérez (2014), Hemmer et al. (2001; 2010), Kurtén (1973), Merriam and Stock (1932), Montellano-Ballesteros and Carbot-Chanona (2009), Simpson (1941), and Rufolo (1998).

Size was evaluated by a scattered plot using the mesiodistal length and buccal-lingual width of the lower canine. Measurements were taken with an analog caliper $( \pm 0.1$ $\mathrm{mm}, \max .150 \mathrm{~mm}$ ) and are given in millimeters $(\mathrm{mm})$. Dental abbreviations are as follows: lower canine, $\mathrm{c} 1$; third lower premolars, p3; fourth lower premolar, p4; and first lower molar, $\mathrm{m} 1$.

\section{Results}

Order Carnivora Bowdich 1821

Family Felidae Fischer de Waldheim 1817

Subfamily Pantherinae Pocock 1917

Genus Panthera Oken 1816

Panthera onca (Linnaeus 1758)

Panthera onca augusta (Leidy 1872) (Figure 1)

Referred material. IGM 9518 is an incomplete right jaw (Figure 1), with preserved c1, but with broken crown, p3, p4, and $\mathrm{m} 1$.

Measurements. c1 length and width: $19.2 \mathrm{~mm}, 16.8$ $\mathrm{mm}$; p3 length and width: $15.1 \mathrm{~mm}, 7.5 \mathrm{~mm}$; p4 length and width: $20.0 \mathrm{~mm}, 10.2 \mathrm{~mm}$; $\mathrm{m} 1$ length and width: $21.1 \mathrm{~mm}$, $10.9 \mathrm{~mm}$. Length dental system (p3-m1): $56.3 \mathrm{~mm}$. Height of the mandibular ramus at the level of p3: $33.8 \mathrm{~mm}$. Height of the mandibular ramus at the level of $\mathrm{m} 1: 31.2 \mathrm{~mm}$.

Locality. IGM 9518 comes from the vicinity of San Luis Soyatlán, Arandas Municipality, Jalisco State (IGMloc 1442). San Luis Soyatlán is located on the southwestern border of the Chapala Lake. Although the exact point of origin of IGM 9518 is unknown, Lucas (2008) mentions for San Luis 
Soyatlán the presence of Quaternary deposits outcrops. The museum label (Figure 2) indicates that this fossil comes from the Early Pleistocene, however this has not been confirmed yet. If it were true, this would be one of the oldest known jaguars in the America continent.

Description and comparison. The specimen represents a large feline (Figure 3 ). Because $\mathrm{c} 1$ is conical and robust it belongs to the pantherine group, unlike the machairodontines where this tooth is more acute and slightly compressed. Also, c1 is larger than those of specimens of in Puma and living jaguars; its size matches with Pleistocene jaguars ( $P$. onca augusta and $P$. onca georgica), but it is not as big as in $P$. atrox (Figure 3 ). Lateral sides of the crown are smooth, while in P. atrox, P. spelaea, and $P$. leo a crest running along the crown is usually appreciated (see "Discussion" for further explanation). The p3 and $\mathrm{p} 4$ have three cusps, where the central cusp (i. e., protoconid) is the largest. A well differentiated posterior cingulum is also present in these teeth. This morphology is also observed in other species of the genus Panthera and Puma; although in P. atrox the p4 cingulum is more differentiated. The $\mathrm{m} 1$ is robust as in other species of Panthera and Puma, and less blade-lake than in machairodontines. The diastema between $\mathrm{c} 1$ and $\mathrm{p} 3$ is less broad than in P. leo and P. atrox.
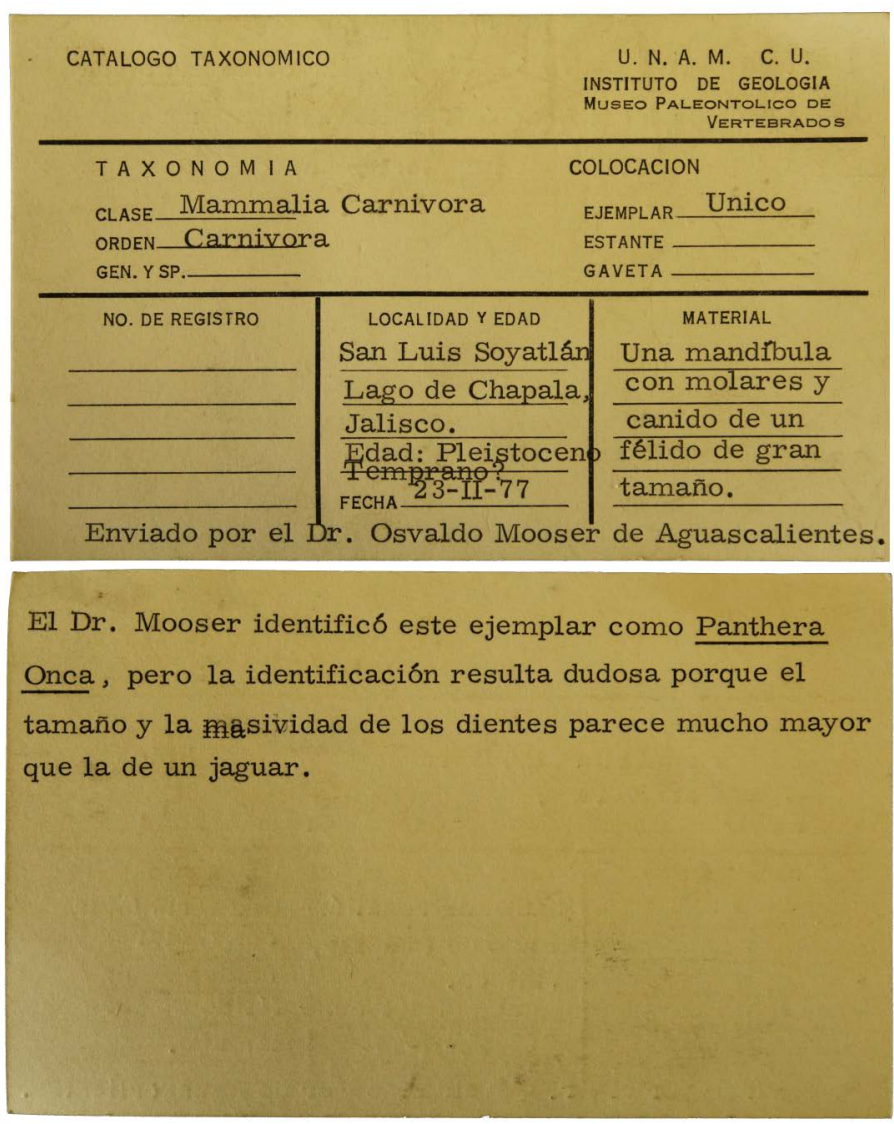

Figure 2. Museum label from 1977, with collecting information of the fossil jaguar (IGM 9518) from San Luis Soyatlán, Jalisco (México). This label shows the doubts of O. Mooser identification: "Dr. Mooser identified this specimen as "Panthera Onca", but the identification is doubtful because the size and massiveness of the teeth seems much greater than that of jaguar" (author's translation).

\section{Discussion}

Taxonomic notes. In the Figure 3 it can be noticed that IGM 9518 is a large felid. In the American continent big felids are represented by pantherines, cougars, and the extinct long-teeth machairodontines (Turner 1997). IGM 9518 differs from machairodontines by its rounded canine and premolars. Also, is larger than any Puma concolor analyzed. Although the Soyatlán jaw is not complete, it can be certain that it belongs to Panthera because its size and dental morphology.

In North America, three species of Panthera have been reported: the extinct cave lion $P$. spelaea, the American lion P. atrox, and the still present jaguar P. onca (Seymour 1989; Barnett et al. 2016). Recently, a new pantherine species, called $P$. balamoides, was reported for the Pleistocene of a Quintana Roo cenote in México (Stinnesbeck et al. 1918), but in our opinion its morphology remember that of ursids, not that of a pantherine; for this reason we do not consider it in our study.

The morphology of IGM 9518 is relatively similar to that of American pantherines species, except for the absence of a crest in the lower canine. Nelson and Goldman (1933) indicate that $P$. onca typically lacks a longitudinal ridge (or groove) in the canines. However, we observe that in the lower canines of some South American members this ridge is present (e. g. MLP 10-9 and MACN 26.217 from Argentina). But, this crest is always present in all the $P$. atrox and $P$. spelaea observed. So, the absence of this crest allows us to refer IGM 9518 to $P$. onca and not $P$. atrox neither P. spelaea.

In 1977, O. Mooser reached the same taxonomical conclusion, however, in the museum's label it can be read that there is a doubt about this assignation; "...the identification is doubtful because the size and massiveness of the teeth seems much greater than that of a jaguar" (Figure 2). Our morphometric analyses corroborate this observation; this specimen does not match in size with any living jaguar, male and female even (see Figure 3). Curiously, this condition was previously observed in other Pleistocene jaguars. Simpson (1941) considered that Pleistocene forms from North America were morphologically similar to the living ones but different in size. Simpson (1941) assigned the fossil specimens to the subspecies $P$. onca augusta (Leidy, 1872), which is 15 to $20 \%$ larger than the living forms (Kurtén 1973; Seymour 1989). Although the subspecies concept is debatable (Wilson and Brown 1953), the usage of subspecific taxa is useful to describe the historical change in size of the P. onca. Seymour (1993) shown that in North America, the living and fossil members of $P$. onca differ in size cranially and postcranially. Also, the material from San Luis Soyatlán is not the only Mexican material that presents a large size. This condition is also present in specimens from San Josecito Cave in Nuevo León, as can be seen in Figure 3.

Past and present range distribution in México. México has few reports of fossil jaguar. Torres (1995), Arroyo-Cabrales (2002), Arroyo-Cabrales (2002), Morales-Mejía et al. (2009), 
and Ferrusquía-Villafranca et al. (2010), listed nine localities; the record here presented adds one additional locality, totaling 10 localities (Table 1; Figure 4). However, not all of these reports have been confirmed as corresponding to Panthera onca. The localities with confirmed material are five: 1) El Cedazo (Aguascalientes), 2) Loltún Grottoes (Yucatán), 3) Mina de San Antonio (San Luis Potosí), 4) San Josecito Cave (Nuevo León), and 5) Soyatlán/Chapala region (Jalisco).

Today, the Mexican jaguar is almost restricted to environments with closed vegetation in the Sierra Madre Occidental-Sierra Madre Sur, Sierra Madre Oriental, Sierra de Tamaulipas, and the Southern part of the country including the Yucatan Peninsula (Ceballos 2014; de la Torre et al. 2017; Quigley et al. 2017; Figure 4). It is important to highlight that only one fossil locality, San Josecito Cave, lies within the current range of the jaguar (see Figure 4). In other words, the only place known in North America where the jaguar has remained since the Pleistocene time is in the Sierra Madre Oriental of Nuevo León, México. Certainly, there are localities that do not match with the range distribution of the living jaguar reported by de la Torre et al. (2017) and Quigley et al. (2017), but they are in areas with a large probability of occurrence of this pantherine (sensu Jędrzejewski et al. 2018) like El Golfo and Rancho La Brisca (Sonora), Cuatro Ciénagas (Coahuila), Mina de San Antonio (San Luis Potosí), and Loltún Grottoes (Yucatán). Despite this, there are four fossil Mexican localities with low probability of occurrence of living jaguars: Brechas Coloradas (San Luis Potosí), Arroyo Cedazo (Aguascalientes), and Zacoalco and Soyatlán (Jalisco; Figure 4).
The reduction in the geographic distribution of jaguar has been previously mentioned. Seymour (1989) and AriasAlzate et al. (2017) shown that during the Middle Pleistocene the range of $P$. onca extended to Canada. Then, during the Late Pleistocene this range was reduced to the United States, probably at the latitude of Virginia and Northern California. Historical data indicates that by the decade of 1950's the jaguar extended to California, Arizona, Nuevo México, and Southeastern Texas, with an already absence in the Mexican Central Plateau (Hall 1959). Quigley et al. (2017) showed that for 2008 the North American distribution was already restricted only to México, and that from 2008 to 2015 a $20 \%$ of declination in the jaguar range. Jędrzejewski et al. (2018) mention that historically the jaguar had a range that covered ca. 1660 thousand $\mathrm{km}^{2}$; currently, this range is of ca. 339 thousand $\mathrm{km}^{2}$. Variation in the distribution and structure of populations have been attributed to climatic changes occurred during the PleistoceneHolocene (Barnosky et al. 2003; Koch and Barnosky 2006; Arroyo-Cabrales et al. 2007; Barnosky 2008; Ceballos 2014; Arias-Alzate et al. 2017). Kurtén and Anderson (1980) and Arias-Alzate et al. (2017) pointed out that the reduction in the range distribution of the jaguar was the product of the influence of glacial and interglacial shifts. In addition, given that the range reduction continues nowadays, it is necessary to consider and discuss other variables, in particular anthropogenic pressure and emerging diseases.

In general, the diversity of the American Quaternary carnivores was deeply affected, where some became completely extinct (e. g. hyenas, long-teeth felines, American

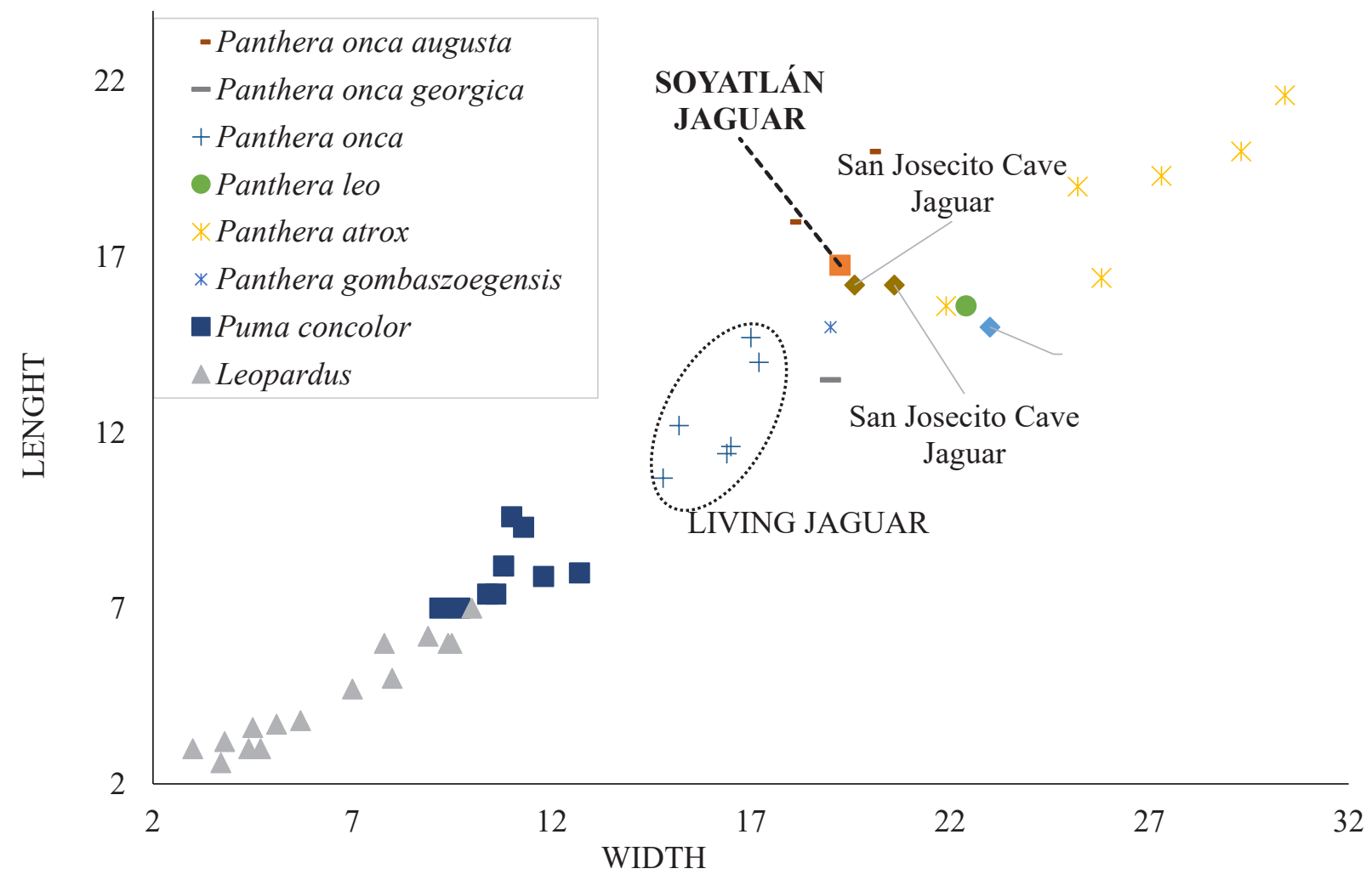

Figure 3. Size relationship (in mm) of the lower canine (c1) of specimen IGM 9518 with respect to other felids. Abbreviations: S. L., San Josecito cave. 
lion, and Dire wolf), others modified their distribution ( $i$. e., local extinction), and few went through phenotypic changes (Koch and Barnosky 2006; Ceballos et al. 2010). In the case of the jaguar, there are evidences of the last two situations: 1) changes in its distribution (Figure 2; 4) changes in its phenotype (they became smaller).

The fossil record of jaguar in the central part of México is evidence that the conditions in the past were favorable for its presence there. The extant jaguar mainly lives in tropical rainforests, sub-deciduous and deciduous forests, and mangroves, and less frequently in conifer or oak forests, and xeric environments (Seymour 1989; Linares 1998; Ceballos 2014). Likely, the localities were fossil jaguars have been recorded during Pliocene-Pleistocene times were areas of close vegetation and environments that favored hunting opportunities (Stinnesbeck et al. 1982; Ceballos et al. 2010). For example, Arroyo El Cedazo, Aguascalientes, central México, currently has a vegetation associated with deserts and high human presence, but during the Rancholabrean time, it was an extensive grasslands or prairie capable of supporting herds of large grazing mammals, where gallery forests probably existed nearby (Mooser and Dalquest 1975). These habitat types are described as suitable hunting area for the jaguar (Crawshaw and Quigley 2002).
Another possibility, compatible with the previous one, is that the potential jaguar prey migrated to the tropical areas where jaguar habits today in México, and that caused the current distribution of this feline, as happened with other carnivores (Ripple et al. 2014).

Curiously, many large mammals became extinct around the World during the Quaternary extinction (Koch and Barnosky 2006; Barnosky 2008; Arias-Alzate et al. 2017), and México was not an exception. Proboscidean (Gomphotheriidae and Mammutidae), xenathran (Glyptodontidae, Megatheriidae, and Mylodontidae), felids (machairodontines and American lion), and canids (Dire wolf), are completely extinct, while Pleistocene camels (Camelidae), and horses (Equidae) became locally extinct (Arroyo-Cabrales et al. 2007, 2010; Ceballos et al. 2010; Arias-Alzate et al. 2017). $P$. onca augusta is not present today in North America, so this large form of the jaguar became locally extinct too, probably due to the same phenomenon of megafauna extinction (Arias-Alzate et al. 2017).

It is important to mention that despite the reduction in the habitat of the jaguar, this species is extremely successful compared to other big extinct felids (i. e., long-teeth felines and American lion). One hypothesis used to explain the extinction of other big felines, is focused on the degree

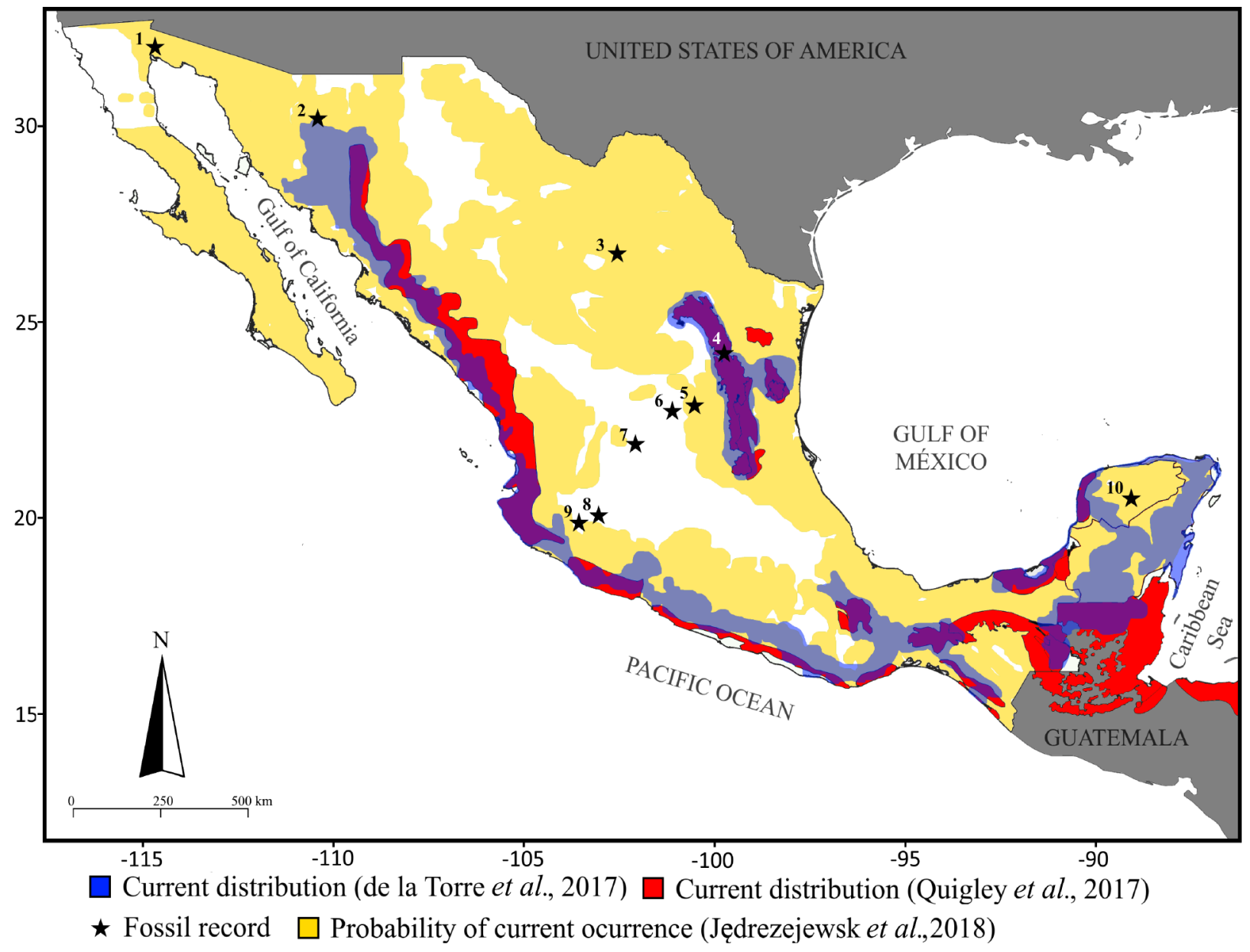

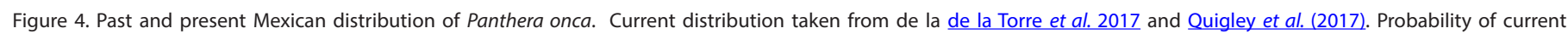

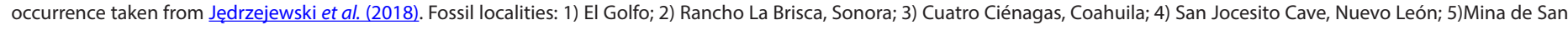

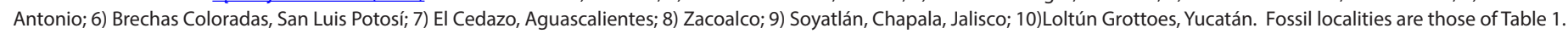


Table 1. Mexican localities with fossil records of Panthera onca. Numbers in parentheses correspond to the localities depicted in Figure 4.

\begin{tabular}{|c|c|c|c|c|}
\hline & Locality & Material & Age & References \\
\hline \multirow[t]{2}{*}{ Sonora } & El Golfo (1) & $\begin{array}{l}\text { Not reported material, but the specimen } \\
\text { was conferred to jaguar specie (Panthera } \\
\text { sp. cf. P. onca) }\end{array}$ & Pleistocene (Irvingtonian) & $\begin{array}{l}\text { Arroyo-Cabrales (2002); Croxen IIl et al. } \\
\text { (2007); Ferrusquía-Villafranca et al. (2010) }\end{array}$ \\
\hline & Rancho La Brisca (2) & Not reported material & $\begin{array}{l}\text { Pleistocene } \\
\text { (Rancholabrean) }\end{array}$ & $\begin{array}{l}\text { Arroyo-Cabrales (2002); Ferrusquía- } \\
\text { Villafranca et al. (2010) }\end{array}$ \\
\hline Coahuila & Cuatro Ciénagas (3) & $\begin{array}{l}\text { Not reported material, and Contreras- } \\
\text { Balderas et al. (2007) points that the report } \\
\text { is doubtful because the material could } \\
\text { also belong to Puma. }\end{array}$ & $\begin{array}{l}\text { Pleistocene } \\
\text { (Rancholabrean) }\end{array}$ & $\begin{array}{l}\text { Contreras-Baldera et al. (2007); Ferrusquía- } \\
\text { Villafranca et al. (2010) }\end{array}$ \\
\hline Nuevo León & San Josecito Cave (4) & $\begin{array}{l}\text { LACM* } 192 / 264 ; 192 / 9008 . \text { Cranial and } \\
\text { postcraneal material }\end{array}$ & $\begin{array}{l}27.000-45.000 \text { YBP } \\
\text { (Rancholabrean) }\end{array}$ & Kurtén (1973); Arroyo-Cabrales et al. (1995) \\
\hline \multirow[t]{2}{*}{ San Luis Potosí } & Mina de San Antonio (5) & $\begin{array}{l}\text { IGM } 6705 ; 6706 ; 6707 . \text { Dental and } \\
\text { postcraneal material }\end{array}$ & $\begin{array}{l}\text { Pleistocene } \\
\text { (Rancholabrean) }\end{array}$ & $\begin{array}{l}\text { Torres (1995); Ferrusquía-Villafranca et al. } \\
\text { (2010) }\end{array}$ \\
\hline & Brechas Coloradas (6) & Not reported material & $\begin{array}{l}\text { Late Pleistocene-Holocene } \\
\text { (Wisconsinian) }\end{array}$ & $\begin{array}{l}\text { Arroyo-Cabrales (2002); Ferrusquía- } \\
\text { Villafranca et al. (2010) }\end{array}$ \\
\hline Aguascalientes & El Cedazo (7) & $\begin{array}{l}\text { IGM 56-102; 56-190; FC } \text { F }^{* *} 613 . \text { Cranial and } \\
\text { postcraneal material }\end{array}$ & $\begin{array}{l}\text { Pleistocene } \\
\text { (Rancholabrean) }\end{array}$ & $\begin{array}{l}\text { Mooser and Dalquest (1975); Arroyo- } \\
\text { Cabrales (2002); Ferrusquía-Villafranca et al. } \\
\text { (2010) }\end{array}$ \\
\hline Jalisco & Zacoalco $^{a}(8)$ & $\begin{array}{l}\text { LACM 1757. Mandibular fragment } \\
\text { conferred to jaguar specie (Panthera sp. }\end{array}$ & Pleistocene (Late Blancan) & $\begin{array}{l}\text { Rufolo (1998); Lucas (2008); Arroyo-Cabrales } \\
\text { (2002) }\end{array}$ \\
\hline \multirow[t]{2}{*}{ Chapala Lake } & & cf. P. onca) & & \\
\hline & Soyatlán (9) & IGM 9518. Mandibular fragment & Early? Pleistocene & New report in this work \\
\hline Yucatán & Lultún Grottoes (10) & $\begin{array}{l}\text { Under review material. Dental and } \\
\text { postcraneal material }\end{array}$ & $\begin{array}{l}\text { Pleistocene } \\
\text { (Rancholabrean) }\end{array}$ & $\begin{array}{l}\text { Arroyo-Cabrales and Álvarez (2003); } \\
\text { Morales-Mejía et al. (2009); Personal review }\end{array}$ \\
\hline
\end{tabular}

of specificity of the diet. $P$. onca is a generalist hypercarnivore, this means that it has the capacity to consume a great diversity of prey, even preys with hard shells, such as turtles or armadillos (Emmons 1989; Seymour 1989). This probably conferred advantages to $P$. onca at the time when the availability of large prey was declining. The same selection process probably happened with the cougar Puma concolor. Both, cougar and jaguar are generalist predators although they have prey separation (Chinchilla 1997).

\section{Acknowledgements}

We would like to thank the curator (J. Alvarado) and the assistants (A. Martínez-Melo, V. Romero) of the Colección Nacional de Paleontología, Instituto de Geología for providing access to Colección Geográfica de Referencia. We extend our thanks to J. Sánchez and F. Bisbal from the Museo de la Estación Biológica Rancho Grande, to G. Takeuchi, A. Farrell, and E. Lindsey from La Brea Tar Pit \& Museum, to P. Teta from Museo Argentino de Ciencias Naturales Bernardino Rivadavia, and M. Reguero from Museo de La Plata. We thank to G. D'Elía and one anonymous reviewer for their comments on an earlier version of the manuscript. DRR thanks the Instituto de Geología for all the support during the development of this project, and the Dirección General de Asuntos del Personal Académico (DGAPA) for the financial support. We extend a posthumous gratitude to $O$. Mooser because his discovery and comments promoted the elaboration of this investigation. Also, DRR thanks to his colleagues (A.MM. and K.C.) for promoting an unexpected renewal of the information contained in this work.

\section{Literature cited}

Arias-Alzate, A., J. González-Maya, J. Arroyo-Cabrales, and E. Martínez-Meyer. 2017. Wild felid range shift due to climatic constraints in the Americas: A bottleneck explanation for extinct felids? Journal of Mammal Evolution 24:427-438.

Arroyo-Cabrales, J. 2002. Registro fósil del jaguar. Pp. 343-354 in El jaguar del nuevo milenio (Medellín, R. A., ed.). Fondo de Cultura Económica, Universidad Nacional Autónoma de México. Ciudad de México, México.

Arroyo-Cabrales, J., AND T. Álvarez. 2003. A preliminary report of the late Quaternary mammal fauna from Loltún Cave, Yucatán, México. Pp. 262-272 in Ice Age Cave Faunas of North America (Schubert, B. W., J. I. Mead, and R. W. Graham, R.W. eds.). Indiana University Press. Bloomington, U.S.A.

Arroyo-Cabrales, J., O. Polaco, and E. Johnson. 2007. An overview of the Quaternary mammals from México. CourierForschungsinstitut Senckenberg 29:191-203.

Arroyo-Cabrales, J., O. Polaco, E. Johnson, and I. FerrusquíaVillafranca. 2010. A perspective on mammal biodiversity and zoogeography in the Late Pleistocene of México. Quaternary International 212:187-197. 
Barnett, R., M. Mendoza, A. R. Soares, S. Ho, G. Zazula, N. Yamaguchi, B. Shapiro, I. Kirillova, G. Larson, and M. Gilbert. 2016. Mitogenomics of the extinct cave lion, Panthera spelaea (Goldfuss, 1810), resolve its position within the Panthera cats. Open Quaternary 2:4.

Barnosky, A. D. 2008. Megafauna biomass tradeoff as a driver of Quaternary and future extinctions. Proceedings of the National Academy of Sciences 105:11543-11548.

Barnosky, A. D., E. A. Hadly, and C. J. Bell. 2003. Mammalian response to global warming on varied temporal scales. Journal of Mammalogy 84:354-368.

Carbot-Chanona, G., and L. E. Gómez-Pérez. 2014. Nueva evidencia de Panthera atrox (Mammalia, Felidae) en el Pleistoceno Tardío de Chiapas. Lacandonia 8:83-89.

Ceballos, G. 2014. Mammals of Mexico. Johns Hopkins University Press. Baltimore, U.S.A.

Ceballos, G., J. Arroyo-Cabrales, and E. Ponce. 2010. Effects of Pleistocene environmental changes on the distribution and community structure of the mammalian fauna of Mexico. Quaternary Research 73:464-473.

Chinchilla, F. A. 1997. La dieta del jaguar (Panthera onca), el puma (Felis concolor) y el manigordo (Felis pardalis) (Carnivora; Felidae) en el Parque Nacional Corcovado, Costa Rica. Revista de Biología Tropical 45:1223-1230.

Contreras-Balderas, A. J., D. J. Hafner, J. H. López-Soto, J. Torres-Ayala, And S. Contreras-Arquieta. 2007. Mammals of the Cuatro Ciénegas Basin, Coahuila, Mexico. Southwestern Naturalist 52:400-409.

Crawshaw, JR., and H. Quigley. 2002. Hábitos alimenticios del jaguar y el puma en el pantanal, Brasil, con implicaciones para su manejo y conservación. Pp. 190-283 in El jaguar del nuevo milenio (Medellín, R. A. ed.). Fondo de Cultura Económica, Universidad Nacional Autónoma de México. Ciudad de México, México.

Croxen III, F. W., C. A. Shaw, and D. R. Sussman. 2007. Pleistocene geology and paleontology of the Colorado River delta at Golfo de Santa Clara, Sonora, Mexico. Pp. 84-89 in Wild, Scenic and Rapid: a trip down Colorado river trough (Reynolds, R. E., ed.). Desert Symposium Field Guide and Abstracts from Proceedings, California State University. Fullerton, U.S.A.

De La Torre, J. A., J. F. González-Maya, H. Zarza, G. Ceballos, AND R. A. Medellín. 2017. The jaguar's spots are darker than they appear: assessing the global conservation status of the jaguar Panthera onca. Oryx 52:300-315.

Diedrich, C. G. 2007. Upper Pleistocene Panthera leo spelaea (Goldfuss, 1810) skeleton remains from Praha-Podbaba and other lion finds from loess and river terrace sites in Central Bohemia (Czech Republic). Bulletin of Geosciences 82:99-117.

Eмmons, L. H. 1989. Jaguar predation on chelonians. Journal of Herpetology 23:311-314.

Ferrusquía-Villafranca, I., J. Arroyo-Cabrales, E. MartínezHernández, J. Gama-Castro, J. Ruiz-González, O. J. Polaco, and E. Johnson. 2010. Pleistocene mammals of Mexico: a critical review of regional chronofaunas, climate change response and biogeographic provinciality. Quaternary International 217:53-104.

González, A. 2019. Panthera balamoides and other Pleistocene felids from the submerged caves of Tulum, Quintana Roo, Mexico. Historical Biology 1-10.
Hall, E. R., and K. R. Kelson. 1959. The mammals of North America. Columbia University Press. New York, U.S.A.

Hemmer, H., And R. D. Kahlke, R. D. 2005. Nachweis des Jaguars (Panthera onca gombaszoegensis) aus dem späten Unter-oder frühen Mittelpleistozän der Niederlande. Deinsea 11:47-58.

Hemmer, H., R. D. Kahlke, and A. K. Vekua. 2001. The JaguarPanthera onca gombaszoegensis (Kretzoi, 1938) (Carnivora: Felidae) in the late lower Pleistocene of Akhalkalaki (South Georgia; Transcaucasia) and its evolutionary and ecological significance. Geobios 34:475-486.

Hemmer, H., R. D. Kahlke, and A. K. Vekua. 2010. Panthera onca georgica ssp. nov. from the Early Pleistocene of Dmanisi (Republic of Georgia) and the phylogeography of jaguars (Mammalia, Carnivora, Felidae). Neues Jahrbuch für Geologie und Paläontologie-Abhandlungen 257:115-127.

Hemmer, H., R. D. Kahlke, and T. Keller. 2003. Panthera onca gombaszoegensis (Kretzoi, 1938) aus den frühmittelpleistozänen Mosbach-Sanden (Wiesbaden, Hessen, Deutschland) e Ein Beitrag zur Kenntnis der Variabilität und Verbreitungsgeschichte des Jaguars. Neues Jahrbuch für Geologie und Paläontologie-Abhandlungen 229:31e60.

Jędrzejewski, W., H. S. Robinson, M. Abarca, K. A. Zeller, G. Velasquez, E. Paemelaere, J. F. Godberg, E. Payan, R. Hoogestejin, E. O. Boede, K. Schmidt, M. Lampo, M., A. L. Viloria, R. Carreño, N. Robinson, P. Lukacs, J. Nowak, R. Salom-Pérez, F. Castañeda, V. Boron, AND H. Quigley. 2018. Estimating large carnivore populations at global scale based on spatial predictions of density and distribution-application to the jaguar (Panthera onca). PloS One 13:e0194719.

Johnson, W. E., E. Eizirik, J. Pecon-Slattery, W. J. Murphy, A. Antunes, E. Teeling, and S. J. O’Brien. 2006. The late Miocene radiation of modern Felidae: a genetic assessment. Science 311:73-77.

Koch, P. L., AND A. D. Barnosky. 2006. Late Quaternary extinctions: state of the debate. Annual Review of Ecology, Evolution, and Systematics 37:215-250.

Kurtén, B., and E. Anderson. 1980. Pleistocene mammals of North America. Columbia University Pres, New York, U.S.A.

KurTén, B. 1973. Pleistocene jaguars in North America. Societas Scientiarum Fennica 62:1-23.

Langlois, A. 2002. Présence de Panthera gombaszoegensis kretzoï, 1938à la GrotteXIV (Cénac-et-Saint-Julien, Dordogne). Paléo, Revue d'Archéologie Préhistorique, 14:213-220.

LinARES, O. J. 1998. Mamíferos de Venezuela. Sociedad Conservacionista Audubon de Venezuela. Caracas, Venezuela.

LucAs, S. G. 2008. Late Cenozoic fossil mammals from the Chapala rift basin, Jalisco, Mexico. Neogene Mammals: New Mexico Museum of Natural History and Science Bulletin 44:39-50.

Marciszak, A. 2014. Presence of Panthera gombaszoegensis (Kretzoi, 1938) in the late Middle Pleistocene of Biśnik cave, Poland, with an overview of Eurasian jaguar size variability. Quaternary International 326:105-113.

Mazák, J. H., P. Christiansen, And A. C. Kitchener. 2011. Oldest known pantherine skull and evolution of the tiger. PLoS One 6:e25483.

Merriam, J. C., And C. Stock. 1932. The Felidae of Rancho La Brea. Carnegie Institution of Washington. Washington, U.S.A. 
Montellano-Ballesteros, M., and G. Carbot-Chanona. 2009. Panthera leo atrox (Mammalia: Carnivora: Felidae) in Chiapas, Mexico. Southwestern Naturalist 54:217-222.

Mooser, O., AND W. W. Dalquest. 1975. Pleistocene mammals from Aguascalientes, central Mexico. Journal of Mammalogy 56:781-820.

Morales-Mejía, F. M., J. Arroyo-Cabrales, and O. J. Polaco. 2009. New records for the Pleistocene mammal fauna from Loltún Cave, Yucatán, Mexico. Paleoenvironments: Vertebrates and Invertebrates 26:166-168.

Nelson, E. W., and E. A. Goldman. 1933. Revision of the jaguars. Journal of Mammalogy 14:221-240.

O'Regan, H. J. 2002. A phylogenetic and palaeoecological review of the Pleistocene felid Panthera gombaszoegensis. Ph.D. dissertation, Liverpool John Moores University. Liverpool. Liverpool, U.K.

Prevosti, F., ANd A. Forasiepl. 2018. Evolution of South American mammalian predators during the Cenozoic: paleobiogeographic and paleoenvironmental contingencies. Springer Geology. Gewerbestrasse, Switzerland.

Quigley, H., R. Foster, L. Petracca, E. Payan, R. Salom, and B. Harmsen. 2017. Panthera onca. In: IUCN 2017. The IUCN Red List of Threatened Species 2017. http://dx.doi.org/10.2305/ IUCN.UK.2017-3.RLTS.T15953A50658693.en. Consulted on 27 May 2018.

Ripple, W. J., J. A. Estes, R. L. Beschta, C. C. Wilmers, E. G. Ritchie, M. Hebblewhite, J. Berger, B. Elmhagen, M. Letnic, M. P. Nelson, J. Schmitz, D. Smith, A. D. Wallach, And A. Wirsing. 2014. Status and ecological effects of the world's largest carnivores. Science 343:1241484.

Rufolo, S. J. 1998. Taxonomy and significance of the fossil mammals of Lake Chapala, Jalisco, Mexico. Master Thesis, Brigham Young University. Utah, U.S.A.

Schultz, C. B., L. D. Martin, and M. R. Schultz. 1985. A Pleistocene jaguar from north-central Nebraska. Transactions of the Nebraska Academy of Sciences 8:93-98.

Seymour, K. 1989. Panthera onca. Mammalian Species 340:1-9. Seymour, K. 1993. Size change in North American quaternary jaguars. Pp. 343-372 in Morphological change in Quaternary mammals of North America (Martin, R. A., and A. D. Barnosky, eds). Cambridge University Press. New York, U.S.A.

Simpson, G. G. 1941. Large Pleistocene felines of North America. American Museum Novitates 1136:1-27.

Solbelzon, L. H., ANd F. Prevosti. 2013. Fossils of South American land carnivores (Carnivora, Mammalia). Pp. 509530 in Molecular population genetics, evolutionary biology and biological conservation of neotropical carnivores (RuizGarcia, M., and J. M. Shostell, eds.). Nova Science Publisher. New York, U.S.A.

Stimpson, C. M., P. S. Breeze, L. Clark-Balzan, H. S. Groucutt, R. Jennings, A. Parton, E. Scerri, T. S. White, and M. D. Petraglia. 2015. Stratified Pleistocene vertebrates with a new record of a jaguar-sized pantherine (Panthera cf. gombaszogensis) from northern Saudi Arabia. Quaternary International 382:168-80.

Stinnesbeck, S. R., W. Stinnesbeck, E. Frey, S. C. Avilés Rojas, M. A. Velázquez, and A. González. 2018. Panthera balamoides and other Pleistocene felids from the submerged caves of Tulum, Quintana Roo, Mexico. Historical Biology: 1-10.
TorRes, J. C. 1995. Fauna local Mina de San Antonio, Pleistoceno de San Luis Potosí y su significación geológicopaleontológico. Bachelor Thesis, Universidad Autónoma del Estado de Morelos, Cuernavaca, México.

Tseng, Z. J., X. Wang, G. J. Slater, G. T. Takeuchi, Q. Lı, J. Liu, AND G. XIE. 2014. Himalayan fossils of the oldest known pantherine establish ancient origin of big cats. Proceedings of the Royal Society B: Biological Sciences 281:20132686.

Turner, A. 1997. The big cats and their fossil relatives. Columbia University Press. New York, U.S.A.

Wilson, E. O., And W. L. Brown JR. 1953. The subspecies concept and its taxonomic application. Systematic Zoology 2:97-111.

Associated editor: Guillermo D'Elía

Submitted: May 13, 2019; Reviewed: June 2, 2019;

Accepted: November 1, 2019; Published on line:December 10, 2019. 